\title{
Zika virus: management of infection and risk
}

\author{
Shazaad S Y Ahmad specialty trainee in infectious diseases and virology ${ }^{12}$, Tejal N Amin clinical \\ research fellow and specialty trainee in obstetrics and gynaecology ${ }^{3}$, Andrew Ustianowski consultant \\ in infectious diseases ${ }^{1}$
}

${ }^{1}$ Northwest Regional Infectious Diseases Unit, North Manchester General Hospital, Pennine Acute Hospitals Trust, Manchester M8 5RB, UK; ${ }^{2}$ Virology Department, Manchester Royal Infirmary, Central Manchester Foundation Trust, Manchester Academic Health Sciences Centre, Manchester M13 9WL, UK; ${ }^{3}$ Department of Obstetrics and Gynaecology, University College London Hospitals NHS Foundation Trust, London, UK

Zika virus has caused a self limiting pyrexial illness from Africa to South-East Asia for decades. Recently it has spread across the Pacific and in 2015 caused infections for the first time in South America. Though usually asymptomatic or of little clinical significance in adults, there is concern about an apparent association between infection in pregnancy and birth defects such as microcephaly. ${ }^{1-3}$ We have no data to characterise the risks of abnormal fetal development and adverse pregnancy outcomes, or to guide testing strategies. In its absence, global health bodies have issued guidance for clinicians on how to minimise the risk of transmission to those who are, or may become, pregnant, and to monitor fetuses that may have been exposed.

We present current management advice for healthcare professionals in non-endemic countries, who may offer advice to individuals concerned about pregnancy and conception before or after travel to an area with Zika virus. Guidance is likely to change as the clinical picture and knowledge base develop, and up to date advice can be accessed from sources such as those listed in box 1 .

An accompanying article $\mathrm{e}^{4}$ discusses the epidemiology and the evidence of what is currently known, including a possible association with Guillain-Barré syndrome.

\section{Example scenario 1}

A 27 year old woman has just returned from Colombia. While she was there she felt mildly unwell. Yesterday she discovered that she was pregnant and is anxious about whether she had Zika virus. She has heard that it will damage her baby's brain.

Take a travel history from pregnant women concerned about, or at risk of, Zika virus infection, and from their male sexual partners. Box 2 lists countries where Zika virus is currently present, such as Colombia. There is no evidence to suggest that Zika virus poses a specific problem for maternal health.

\section{The risk of congenital abnormalities is poorly characterised}

The risk of Zika virus infection to a developing fetus is not fully understood. The recent rise in such infections has coincided with an apparent increase in birth defects-predominantly microcephaly but also ventriculomegaly, cell migration abnormalities, congenital contractures, stillbirth, and neonatal death. ${ }^{25}$ These abnormalities have largely been described in case reports and case series. A direct causal link has not been confirmed, but there is evidence of Zika virus infection in placentas of aborted fetuses and in the brains of babies with microcephaly who died soon after birth ${ }^{67}$ If causality is established, further data will be needed before we could tell a pregnant woman how likely it is that she would have an affected child.

Preliminary data from a small case series suggest that infection in the early stages of pregnancy may pose the greatest risk, ${ }^{5}$ consistent with other viral infections such as rubella. No treatment is presently available to correct or alter the chances of adverse fetal outcomes.

\section{Testing and monitoring of pregnant women is guided by symptoms}

There is an absence of good evidence to guide testing and monitoring. However, expert guidance has been issued by international bodies.

Figure $1 \Downarrow$ shows UK guidance for pregnant women who have travelled to an area with known Zika virus transmission during the pregnancy. ${ }^{1}$ In essence, all pregnant women who have travelled to an area affected by Zika virus should be offered a baseline fetal ultrasound scan and should be discussed with a secondary care obstetric team. If the ultrasound is normal, offer scans every four weeks throughout the pregnancy. Microcephaly 


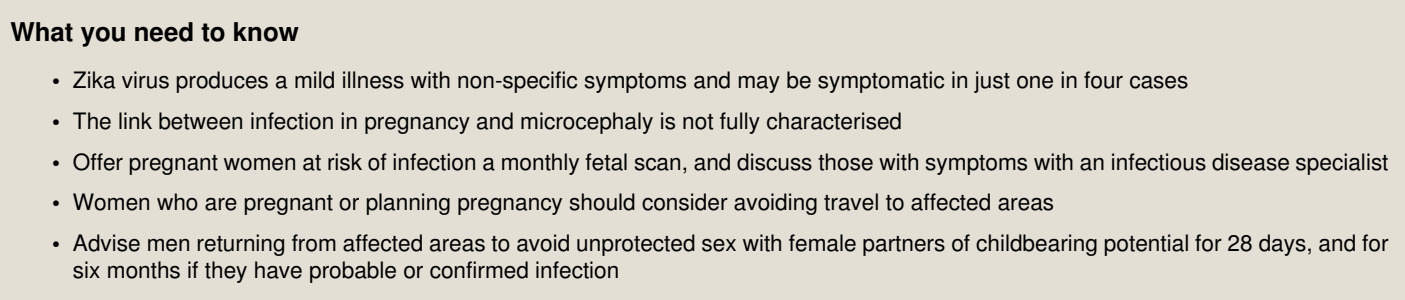

Box 1: Sources of up to date advice on Zika virus and management of those exposed

- Public Health England-www.gov.uk/guidance/zika-virus

- Royal College of Obstetricians and Gynaecologists-www.rcog.org.uk/en/news/interim-clinical-guidelines-on-zika-virus-infection-andpregnancy/

- National Travel Health Network and Centre $(\mathrm{NaTHNaC})$ for travel advice-http://travelhealthpro.org.uk/zika-virus-update-and-advicefor-travellers-including-pregnant-women/

- Health Protection Scotland-www.hps.scot.nhs.uk/internationalissues/zika.aspx

- European Centre of Disease Control—http://ecdc.europa.eu/en/healthtopics/zika_virus_infection/Pages/index.aspx

- Centers for Disease Control and Prevention-www.cdc.gov/zika/

- Australian Department of Health-www.health.gov.au/internet/main/publishing.nsf/Content/ohp-zika.htm

- World Health Organisation-www.who.int/csr/disease/zika/en/

and the other neurological abnormalities described may not become apparent on scans until after 20 weeks' gestation or into the third trimester. Logistically, testing and care may be led by obstetric teams or form part of joint care with midwives or primary care doctors.

Detection of any neurological abnormalities, such as a small head (more than two standard deviations below the mean for gestational age) or intracranial calcifications, warrants referral to a fetal medicine unit for further investigation. Here, alternative causes of microcephaly-such as other congenital infections, chromosomal abnormalities and undefined genetic syndromes, exposure to teratogenic substances, and maternal metabolic diseases - will also be considered.

Pregnant women who present with clinical symptoms compatible with Zika virus infection (see box 3) while in, or within two weeks of return from, a Zika virus affected area should be considered for testing for Zika virus infection and other travel associated diseases relevant to the country of travel. Those who are asymptomatic but have just returned should be advised to seek medical care if they develop any symptoms consistent with Zika virus within the next two weeks.

\section{Interpreting tests for Zika virus is complicated}

All patients undergoing testing for Zika virus infection should be discussed with infection specialists and the optimum testing strategy for this and any other infections agreed. The first line test and definitive diagnosis is made by identification of Zika virus RNA by means of PCR (polymerase chain reaction). This may remain detectable in blood for the first five days of infection and probably for up to two weeks in urine. ${ }^{8}$ Use the test in those with current or recent symptoms in liaison with the local virology laboratory. (In the UK this is generally serum and an EDTA blood sample, and also urine in sterile container if the patient is pregnant.)

If Zika virus RNA is detected, UK guidance suggests that the woman is offered direct referral to fetal medicine specialists. However, a negative PCR result cannot exclude infection (especially if the sample is sent several days after the onset of any symptoms), and follow-up with screening ultrasound scans at four-weekly intervals should be offered in this situation.
The United States uses a Zika virus IgM assay, and Australia is using $\operatorname{IgM}$ and $\operatorname{IgG}$ assays in an attempt to detect infections, including in those outside the testing window for viral RNA. The US Centers for Disease Control and Prevention advocates that all pregnant women returning from affected areas should be tested for Zika virus, ${ }^{9}$ with PCR tests if symptomatic and serological tests if asymptomatic.

The sensitivity, specificity, and applications of such serological tests (IgG or $\operatorname{IgM})$ are not established, however. They are not currently advocated in the UK, although storage of a serum sample for potential future testing (once assays have been established and validated) may be suggested.

Amniotic fluid, if sampled, may also be tested by PCR, but the utility of such testing is not firmly established at present.

\section{Example scenario 2}

A 28 year old man has returned from Brazil and has flu-like symptoms. He is worried that he has Zika virus. He is not sure he should go to work. He has also heard that it can be sexually transmitted and is worried about his partner.

\section{Discuss all those with symptoms and relevant travel history with local infection specialists}

It is estimated that four out of five people with Zika virus infection are asymptomatic, and in those who do develop symptoms these are often non-specific (box 3). It is therefore important that the case of a symptomatic individual, such as described above, is discussed with a local infection specialist to allow assessment for other potential infections such as malaria and dengue.

Zika infection is not a notifiable disease in the UK, but it is in other countries such as the US and Australia.

\section{Zika is transmitted via a type of mosquito but possibly also by semen or blood products}

There is no need to avoid work or other activities of daily living. Zika virus is transmitted from human to human via a vector, the Aedes mosquitoes. These mosquitoes are not present in the UK, northern Europe, Canada, northwestern United States, 


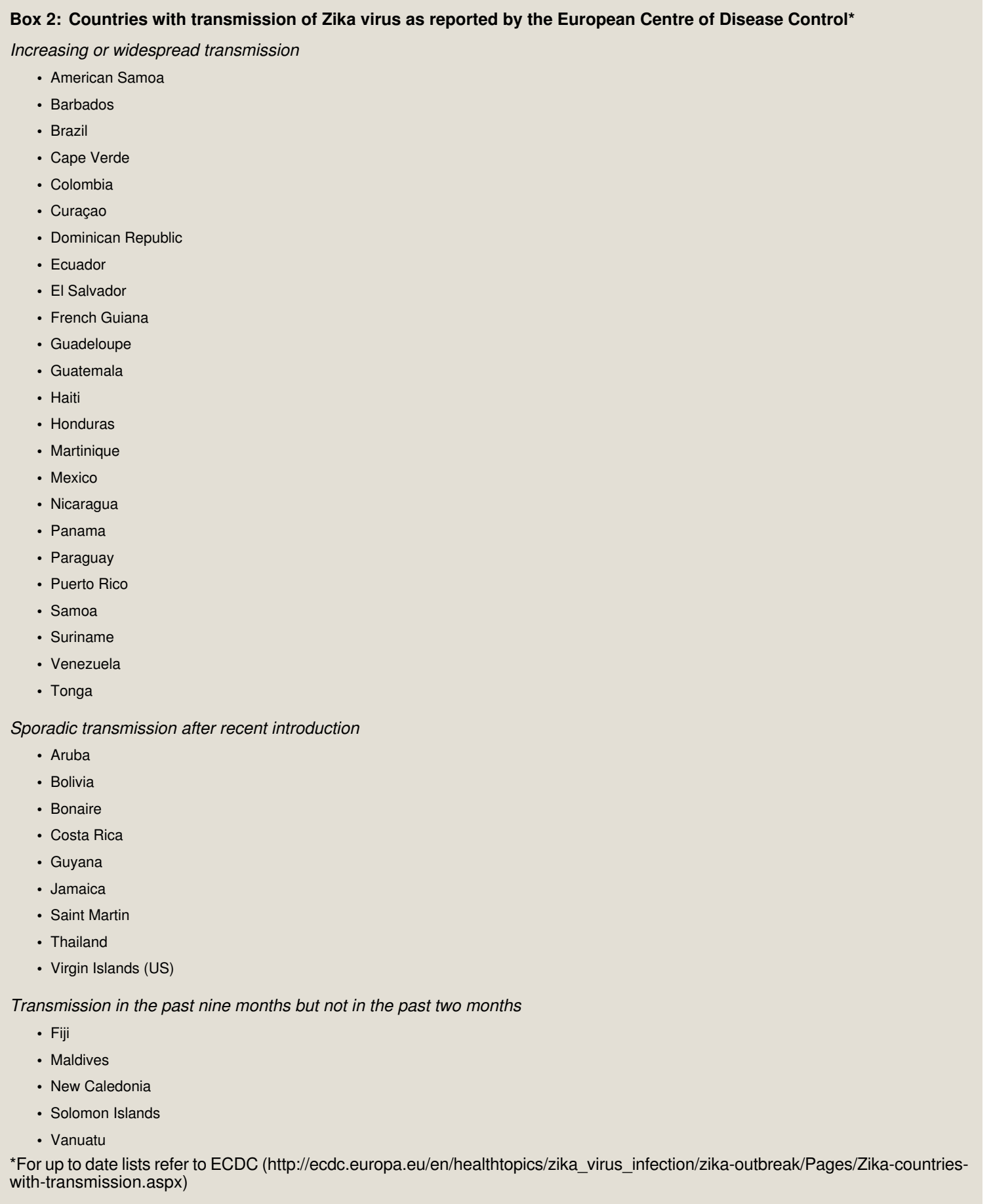

\section{Box 3: Clinical symptoms consistent with Zika virus infection'}

Suspect Zika virus infection in those who have any of the following symptoms and relevant travel history:

- Low grade fever

- Arthralgia

- Maculopapular rash (sometimes itchy)

- Conjunctivitis

- Headache

- Myalgias

- Eye pain

Russia, northeastern Asia, and southern Australia, but they are widespread throughout much of the rest of the world.

It is possible that Zika virus may pass from human to human via other routes. There is a theoretical risk of transmission via infected blood or blood products. ${ }^{10}$ The virus has been identified in semen from two men infected with Zika virus, ${ }^{11}{ }^{12}$ and, to date, there have been two reported instances of sexual transmission by male travellers to their partners in non-endemic 
areas (only one of these cases is presently published ${ }^{13}$ ). It is not known how long after infection the virus is detectable, or potentially infectious, in semen. There is no evidence of sexual transmission from women to men.

UK and European guidance advises that men with suspected or confirmed infection should use condoms with their partners (if pregnant or at risk of pregnancy) for six months. ${ }^{12}$ Abstaining would be another option. The US advises abstaining or using condoms for the duration of the pregnancy if the partner is pregnant, but does not specify a time period if they are not. ${ }^{14}$

For men who have been asymptomatic during travel in affected areas and for two weeks after return, UK and European guidance suggests that they consider using condoms for 28 days after their return if their partner is pregnant or at risk of pregnancy. ${ }^{12}$ The US guidelines do not specify a time period for asymptomatic men. The current advice is that condoms should be used for vaginal, oral, and anal sex. This should be discussed with patients.

These time periods are poorly evidence based. The 28 day window has been suggested to allow a 14 day incubation period and a 14 day viraemic period, even in asymptomatic people. The six month window may change once longer term data on seminal carriage is established.

Patients planning to donate blood, tissue, or semen should declare recent travel to affected areas (and Zika virus test results where known) before donation.

\section{Example scenario 3}

A 32 year old woman is planning to travel on a work trip to Brazil. She is not pregnant but is contemplating starting a family soon. She asks how long risks may persist and wonders how to minimise the chance of infection.

\section{Risk to future pregnancies is unknown}

There are few data to support advice on the duration of risk after potential exposure, but guidance has been issued. There is consensus across UK, ${ }^{1}$ European, ${ }^{2} \mathrm{US},{ }^{3}$ and Australian ${ }^{15}$ guidance that women of childbearing potential who are travelling to Zika affected areas should ensure they are using reliable contraception and should avoid conceiving. Women who are pregnant should be strongly advised to avoid such travel if possible.

On return from endemic areas, advice in the UK is to avoid becoming pregnant for a further 28 days. ${ }^{1}$ It is thought, though with little evidence, that a fetus conceived after a woman has cleared the virus would not be at risk of birth defects, nor should there be any risks to future pregnancies. ${ }^{3}$ There is no known site of longer term carriage (such as in semen) in women.

\section{Advise all travellers on how to avoid mosquito bites}

If travel to an affected area is unavoidable, healthcare providers should fully inform the individual on avoidance of mosquito bites. Aedes mosquitoes bite from dawn through to dusk (only rarely at night), and 24 hour preventive measures should be encouraged. DEET based insect repellents should be used and applied frequently, and other measures should be pursued (see box 4).

Contributors: All authors contributed to drafts and revisions of the manuscript and approved the final version for publication. AU is the guarantor.

Competing interests: We have read and understood BMJ policy on declaration of interests and have no relevant interests to declare.

Provenance and peer review: Commissioned; externally peer reviewed.

1 Royal College of Obstetricians and Gynaecologists, Royal College of Midwives, Public Health England, et al. Interim RCOG/RCM/PHE/HPS clinical guidelines: Zika virus infection and pregnancy information for healthcare professionals. 2016. www.rcog.org.uk/en/news/ interim-clinical-guidelines-on-zika-virus-infection-and-pregnancy

2 European Centre for Disease Prevention and Control. Rapid risk assessment. Zika virus disease epidemic: potential association with microcephaly and Guillain-Barré syndrome (2nd update). 2016. http://ecdc.europa.eu/en/healthtopics/zika_virus_infection/Pages/ index.aspx.

3 Petersen EE, Staples JE, Meaney-Delman D, et al. Interim guidelines for pregnant women during a Zika virus outbreak-United States, 2016. MMWR Morb Mortal Wkly Rep 2016;65:30-3. doi:10.15585/mmwr.mm6502e1. .26796813.

4 Basarab M, Bowman C, Aarons EJ, Cropley I. Zika virus. BMJ 2016;352:11049. doi:10. 1136/bmj.i1049

5 Schuler-Faccini L, Ribeiro EM, Feitosa IML, et al. Brazilian Medical Genetics Society-Zika Embryopathy Task Force. Possible association between Zika virus infection and microcephaly—Brazil, 2015. MMWR Morb Mortal Wkly Rep 2016;65:59-62. doi:10.15585/ mmwr.mm6503e2. .26820244.

6 Martines RB, Bhatnagar J, Keating MK, et al. Notes from the Field: Evidence of Zika virus infection in brain and placental tissues from two congenitally infected newborns and two fetal losses-Brazil, 2015. MMWR Morb Mortal Wkly Rep 2016;65:159-60. doi:10.15585/ mmwr.mm6506e1. 26890059

7 Mlakar J, Korva M, Tul N, et al. Zika virus associated with microcephaly. N Engl J Med 2016;10. doi:10.1056/NEJMoa1600651. .26862926.

8 Gourinat A-C, O'Connor O, Calvez E, Goarant C, Dupont-Rouzeyrol M. Detection of Zika virus in urine. Emerg Infect Dis 2015;21:84-6. doi:10.3201/eid2101.140894. .25530324.

9 Oduyebo T, Petersen EE, Rasmussen SA, et al. Update: interim guidelines for health care providers caring for pregnant women and women of reproductive age with possible Zika virus exposure-United States, 2016. MMWR Morb Mortal Wkly Rep 2016;65:122-7. doi:10.15585/mmwr.mm6505e2. .26866840.

10 Musso D, Nhan T, Robin E, et al. Potential for Zika virus transmission through blood transfusion demonstrated during an outbreak in French Polynesia, November 2013 to February 2014. Euro Surveill 2014;19:14-6. doi:10.2807/1560-7917.ES2014.19.14. 20761. 24739982.

11 Musso D, Roche C, Robin E, Nhan T, Teissier A, Cao-Lormeau VM. Potential sexual transmission of Zika virus. Emerg Infect Dis 2015;21:359-61. doi:10.3201/eid2102. 141363. 25625872 .

12 Atkinson B, Hearn P, Afrough B, et al. Detection of Zika virus in semen. [letter] Emerg Infect Dis 2016. doi:10.3201/eid2205.160107.

13 Foy BD, Kobylinski KC, Chilson Foy JL, et al. Probable non-vector-borne transmission of Zika virus, Colorado, USA. Emerg Infect Dis 2011;17:880-2. doi:10.3201/eid1705. 101939. .21529401.

14 Oster AM, Brooks JT, Stryker JE, et al. Interim guidelines for prevention of sexual transmission of Zika virus-United States, 2016. MMWR Morb Mortal Wkly Rep 2016;65:120-1. doi:10.15585/mmwr.mm6505e1. .26866485.

15 Australian Government Department of Health. Zika virus-information for clinicians and public health practitioners. 2016. www.health.gov.au/internet/main/publishing.nst/Content/ ohp-zika-health-practitioners.htm

Published by the BMJ Publishing Group Limited. For permission to use (where not already granted under a licence) please go to http://group.bmj.com/group/rights-licensing/ permissions 


\section{Box 4: Mosquito bite avoidance}

- Wear long-sleeved shirts and long trousers

- Stay in places that use window and door screens to keep mosquitoes outside or have closed windows and air conditioning

- Sleep under a mosquito bed-net.

- Use mosquito repellents that contain 50\% DEET ( $N, N$-diethyl-m-toluamide) (deemed safe in pregnancy)

- Apply DEET after sunscreen

- Treat clothing with permethrin or purchase permethrin treated items. See product information to determine how long the protection will last

- Public Health England's "Mosquito bite avoidance for travellers" information sheet is available from www.gov.uk/government/publications/ mosquito-bite-avoidance-for-travellers

\section{How were patients involved in the creation of this article?}

The BMJ did not ask the authors to involve patients in the creation of this article.

\section{Figures}

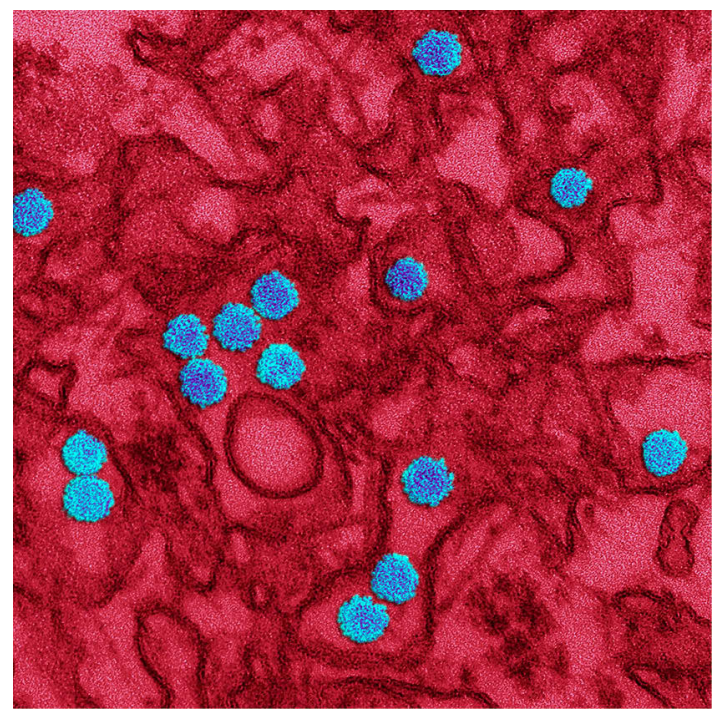

[Image: AMI IMAGES / SPL]

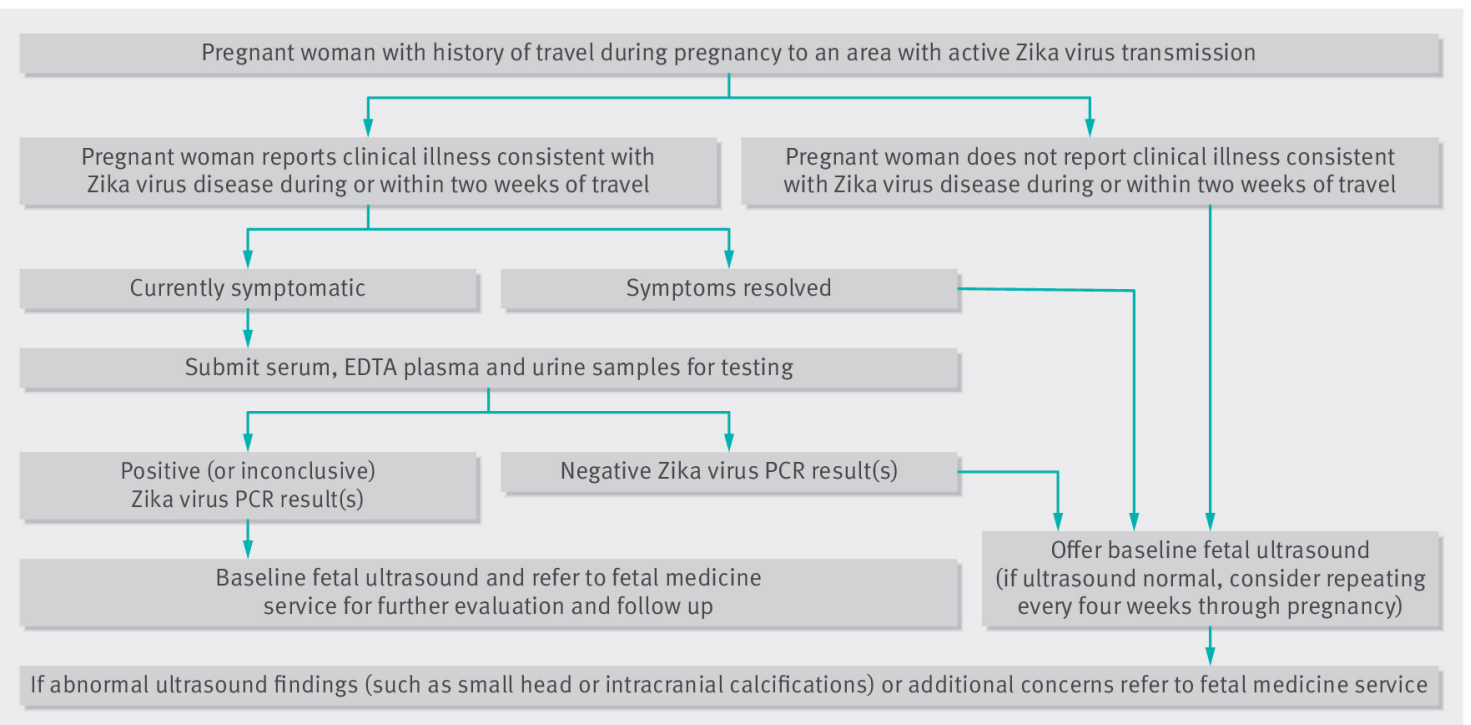

Fig 1 Algorithm for assessing pregnant women exposed to Zika virus ${ }^{1}$ 
